

\section{Sumário}

INOVAÇÃO INSTITUCIONAL E RESISTÊNCIA CORPORATIVA: O PROCESSO DE INSTITUCIONALIZAÇÃO E LEgitimaçÃo do Conselho NaCional de JustiçA .............................................................14 Leandro Molhano Ribeiro e Christiane Jalles Paula

A responsabiLIDADE SOCIAL DA MAGISTRATURA BRASILEIRa: ACCOUNTABILITY E RESPONSIVIDADE EM MEIO À TENSÃO ENTRE O DEVER DE PRESTAR CONTAS E A GARANTIA DA INDEPENDÊNCIA JUDICIAL .30

Marcelo Roseno de Oliveira

THE END OF THE WORLD AS THEY KNEW IT: SHOULD FORMER JUDGES BE DENIED ADMISSION TO THE BAR AFTER THE TRANSITION TO DEMOCRACY?

Stefan Kirchner

CONDICIONANTES E DIRETRIZES DE POLÍTICAS PÚBLICAS: UM ENFOQUE COMUNITARISTA DA TRANSFORMAÇÃO SOCIAL

João Pedro Schmidt

GESTÃo PÚBLICA E PARCERIAS PÚBLICO-PRIVADAS: TEORIA DO ESTADO E TECNOLOGIAS DE GOVERNANÇA DIFUSA PARA CONTROLE SOCIAL

Thiago Souza Araujo, Kinn Peduti de Araujo Balesteros da Silva e Aires Jose Rover

A titularidade dos direitos fundamentais por parte de pessoas jurídicas. A empresa COMO AGENTE DE EFETIVAÇÃO DOS DIREIRTOS SOCIAIS: NOTAS INTRODUTÓRIAS AO DIREITO EMPRESARIAL CONSTITUCIONAL 100

Arnaldo Sampaio de Moraes Godoy e Patrícia Perrone Campos Mello

DA TEORIA OBJETIVA DA DESCONSIDERAÇÃO DA PERSONALIDADE JURÍDICA E OS GRUPOS DE SOCIEDADES SOB A ÓTICA DAS RELAÇÕES DE CONSUMO

Daniel Amin Ferraz e Marcus Vinicius Silveira de Sá

A inversão do ônus da prova e a Teoria da Distribuição Dinâmica: SEmelhanças e inCOMPATIBILIDADES 141

Leonardo Roscoe Bessa e Ricardo Rocha Leite 
A ClÁusula de INTERdição de CONCORRÊNCIA NO DIREITO BRASILEIRO E SUA FUNDAMENTAÇÃo histórica: o Caso da Companhia dos Tecidos de Juta (1914). Notas Sobre SEUS Reflexos NORMATIVOS, DOUTRINÁRIOS E JURISPRUDENCIAIS 157

Arnaldo Sampaio de Moraes Godoy e Daniel Amin Ferraz

Conditional cash transfers (CCT) in Latin America: Analyzing their potentials and Challenges special reference to the Argentine Republic 178 Luciano Carlos Rezzoagli, Gonzalo Chiapello e Florencia Cabrera

A CONTRADIÇÃo ENTRE A REgULAMENTAÇÃo EXISTENTE E A COMPLEXIDADE DOS FATOS REAIS NO CASO DAS DROGAS PARA DOENÇAS NEGLIGENCIADAS 194 Marcos Vinício Chein Feres, Lorena Abbas da Silva, Pedro Henrique Oliveira Cuco e Alan Rossi Silva

A efetividade da lei maria da Penha quanto À orientação SEXual........................... 210 Francisco Antonio Morilhe Leonardo

Transexualidade e o "Direito dos banheiros" no STF: uma reflexão À luz de Post, SIEGEL E FraSER ......................................................................................223 Maria Eugenia Bunchaft

ChINA'S NEW CONCEPT OF DEVELOPMENT FROM THE PERSPECTIVE OF THE SUSTAINABLE DEVELOPMENT GOALS...................................................................................245

Di Zhou

CONTAMINAÇÃo MiCrobIológICA dA ÁGUA: PERSPECTIVAS A PARTIR DO DiÁlOGO ENTRE AS FONTES DO DIREITO 260 Patrícia Maino Wartha, Haide Maria Hupffer, Gustavo da Silva Santanna e Fernando Rosado Spilki

Solar panels in Brazil: a FEASible PUblic POLICY 279 Henrique Pissaia de Souza

UNIDADES DE CONSERVAÇÃO, TERRAS INDÍGENAS E QUILOMBOLAS NO ESTADO DO AMAPÁ: COMO DESENVOLVER UM ESTADO CUJO TERRITÓRIO ESTÁ 70\% PROTEGIDO POR LEIS? .290 Linara Oeiras Assunção

A educaÇão diferenciada como política pública de inClusão social dos Guarani e Kaiowá no Estado do Mato Grosso do Sul 310 Isabelle Dias Carneiro Santos 
ESTADO E RELIGIÃO. O DIREITO CONSTITUCIONAL BRASILEIRO E O CRISTIANISMO: INVENTÁRIO DE POSSIBILIDADES ESPECULATIVAS, HISTÓRICAS E INSTRUMENTAIS

Arnaldo Sampaio de Moraes Godoy e Patrícia Perrone Campos Mello

O RiO E A CIDADE: O DiÁlogo JURÍDico ENTRE O PLANO HÍDRICO E O PLANO DIRETOR .........360 Clarissa Ferreira Macedo D'Isep 


\title{
A titularidade dos direitos fundamentais por parte de pessoas jurídicas. A empresa como agente de efetivação dos direirtos sociais: notas introdutórias ao direito empresarial constitucional*
}

\author{
Legal persons and the ownership of \\ fundamental rights. The corporation as \\ an agent of enactment of social rights: \\ introductory remarks to constitucional business \\ law
}

Arnaldo Sampaio de Moraes Godoy**

Patrícia Perrone Campos Mello***

\section{Resumo}

O ensaio explora o tema da pessoa jurídica e de sua titularidade para o exercício de direitos fundamentais. Argumenta que a efetivação de direitos sociais decorre, também, de instrumentalização das empresas para que possam melhor desempenhar suas funções, inclusive sociais. Como consequência, discute a ampliação da garantia jurisprudencial para que empresas possam atuar melhor, especialmente a partir da jurisprudência do Supremo Tribunal, que já se pronunciou, eventualmente, sobre a matéria, forte no argumento de que há direitos fundamentais que não se aplicam às pessoas jurídicas, por razões de ordem lógica e fatual.

Palavras-chave: Empresa. Direitos fundamentais. Pessoa jurídica. Direitos sociais. O papel do Supremo Tribunal Federal.

* Recebido em 20/11/2016 Aprovado em 20/11/2016

** Livre-docente pela Faculdade de Direito da Universidade de São Paulo-USP. Doutor e Mestre pela Pontifícia Universidade Católica de São Paulo-PUC-SP. Professor do Programa de Mestrado e Doutorado em Direito do UniCEUB.

*** Doutora e Mestre pela Universidade Estadual do Rio de Janeiro -UERJ. Professora do Programa de Mestrado e Doutorado em Direito do UniCEUB.

\section{Abstract}

The paper argues that the implementation of social rights may be enlarged by the empowerment of the corporations, so they can better fulfill their social tasks. It addresses the issue of fundamental rights as a constitutional framework for the corporations. It discusses the enlargement of constitutional guarantees in the favor of corporations, especially in the milieu of the Brazilian Supreme Court, which has already addressed the subject, strong in the argument that some fundamental rights do not apply to the corporations, for logical and factual reasons.

Keywords: Corporation. Fundamental rights. Social rights. The role of the Brazilian Supreme Court. 


\section{INTRODUÇÃO E CONTORNOS DO PROBLEMA}

Educação, saúde, alimentação, trabalho, moradia, transporte, lazer, segurança, previdência social, proteção à maternidade e à infância, bem como a assistência aos desemparados, compõem a agenda dos direitos sociais, nos exatos termos da Constituição Federal vigente ${ }^{1}$. Esse conjunto expressivo de direitos, efetivamente, representa custos, suportados boa parte das vezes pelo Estado, que depende de políticas firmes de arrecadação e de alocação de recursos ${ }^{2}$, a exemplo, especialmente, do sistema de previdência social ${ }^{3}$. O quanto de Estado que precisa ser mobilizado para a solução ótima dessas demandas é assunto que agita discussões que aproximam Economia e Direito Constitucional ${ }^{4}$.

Sob a ótica desse último, o Direito Constitucional, prevalece o dogma da supremacia da Constituição e seu principal traço distintivo, isto é, "sua posição hierárquica superior à das demais normas do sistema"”. Há uma força normativa ${ }^{6}$ que instrumentaliza arranjos institucionais ${ }^{7}$, procedimentais, concebidos com o objetivo de concretizar, no mundo fático, determinações legislativas, que são, também, substancialmente, políticas ${ }^{8}$; as instituições importam ${ }^{9}$ e, também, se definem no contexto de um Estado Constitucional de Direito $^{10}$.

Ainda do ponto de vista do Direito Constitucional e da Teoria do Direito em suas linhas gerais, o ensaio parte da premissa de que a definição de fins, por parte do sistema normativo, implica na disposição de meios. Sustentamos que empresas (pessoas jurídicas) são essenciais para a efetivação de direitos sociais (fins), porque produzem, empregam, arrecadam, distribuem e, por isso, devem ser titularizadas com prerrogativas, também, inerentes às pessoas humanas, quando possível, em que pese algum dissenso, que será apresentado e enfrentado.

Predica-se dessa lógica, que é a lógica das ciências sociais aplicadas, que a inexistência de meios para a consecução de fins, no caso dos direitos sociais, implicaria a identificação dessas prerrogativas com conteúdos metafísicos de análise social e não com políticas e ações concretas. Sem políticas e ações concretas, os direitos sociais não transcendem de mera promessa política. A ordem econômica, isto é, "o tratamento jurídico disciplinado pela Constituição para a condução da vida econômica da Nação" "11 e os arranjos dela decorrentes, deve ser afinada com a ordem social fixada pela mesma estrutura normativa. Assim, mencionada ordem econômica, que juristas veem como parcela da ordem jurídica ${ }^{12}$ (o que não se trata absolutamente

1 BRASIL. Constituição (1988). Constituição da República Federativa do Brasil. Disponível em: <http://www.planalto.gov.br/ccivil_03/Constituicao/Constituicao.htm>. Acesso em: 14 nov. 2016.

2 Nesse tema, por todos, HOLMES, Stephen; SUNSTEIN, Cass. The cost of rights-why liberty depends on taxes. New York, London: W. M. Norton, 1999. Trata-se de um dos mais importantes livros de Direito e políticas públicas publicado nos Estados Unidos no fim do século passado. Stephen Holmes leciona em Nova Iorque (New York University Law School) e Cass Sunstein é professor em Chicago (University of Chicago). Para esses autores, "direitos são serviços públicos que o Governo presta em troca de tributos".

3 GIAMBIAGI, Fabio; ALÉM, Ana Cláudia. Finanças públicas: teoria e prática no Brasil. São Paulo: Campus-Elsevier, 2011. p. 279 e ss. GIAMBIAGI, Fábio. Reforma da previdência: o encontro marcado. São Paulo: Campus-Elsevier, 2007.

4 Conferir, também por todos, NUSDEO, Fábio. Curso de economia: introdução ao direito econômico. São Paulo: Revista dos Tribunais, 2016. p. 173 e ss.

5 BARROSO, Luís Roberto. Interpretação e aplicação da constituição. São Paulo: Saraiva, 2009. p. 372.

6 A construção conceitual de força normativa da Constituição, no sentido da plena aplicabilidade do texto constitucional, é explicitada em: HESSE, Konrad. A força normativa da constituição. Porto Alegre: Sergio Antonio Fabris Editor, 1991.

7 O tema da orientação do modelo jurídico para a construção de arranjos instuticionais que resultem em uma melhora de vida para todos, especialmente no contexto do experimentalismo democrático, é explorado por UNGER, Roberto Mangabeira. What should legal analysis become? London: Verso, 1996.

8 As relações entre direito e política, com ênfase na tese de que aquele primeiro é o resultado direto e empírico desta última são explorados por UNGER, Roberto Mangabeira. The critical legal studies movement. Cambridge: Harvard University Press, 1986. Para uma crítica e um contraponto, ALTMANN, Andrew. Critical legal studies: a liberal critique. New Jersey: Princeton University Press, 1993.

9 NORTH, Douglass C. Institutions, institutional change and economic perfomance. Cambridge: Cambridge University Press, 2007.

10 Conceito desenvolvido por BARROSO, Luís Roberto. Curso de direito constitucional contemporâneo. São Paulo: Saraiva, 2009. p. 243 e ss.

11 FIGUEIREDO, Leonardo Vizeu. Lições de direito econômico. Rio de Janeiro: Forense, 2011. p. 37.

12 GRAU, Eros Roberto. A ordem econômica na constituição de 1988. São Paulo: Malheiros, 2010. p. 68 e ss. 
de consenso doutrinário ${ }^{13}$ ) deve contar com fórmulas e mecanismos que propiciem a realização da ordem social pretendida pela política dominante e traduzida na Constituição.

Direitos sociais previstos no texto constitucional se realizam na proporção e razão diretas da eficiência do ambiente econômico. Há vínculo entre determinação constitucional e aspectos materiais da vida real. A opção pela fundamentamentação da República nos parâmetros de valores sociais do trabalho e da livre iniciativa ${ }^{14}$ sugere aproximação entre categorias de justiça social e de livre mercado ${ }^{15}$, com alguma preponderância pela atuação do tomador de riscos, isto é, do empresário ${ }^{16}$, que é quem exerce, profissionalmente, atividade econômica organizada para a produção ou a circulação de bens ou de serviços ${ }^{17}$, também por intermédio de uma empresa. Há deveres sociais a serem prestados pelas empresas, naturalmente na pessoa de seus controladores ${ }^{18}$.

A empresa é entidade que atua no regime de livre mercado, comprando, vendendo, contratando, lucrando, perdendo, recolhendo tributos, movimentando a economia, em ambiente de trocas contínuas: o mercado. A definição de mercado é hierática; o mercado é mencionado como um sujeito, anônimo, independente da vontade de alguém, dotado de personalidade marcante, cuja vontade não se contraria ${ }^{19}$; justifica ações governamentais, influencia na tomada de decisões das pessoas. É o ambiente no qual a empresa protagoniza seu papel no mundo econômico.

Para que possa se empenhar na realização dos fins fixados pela Constituição, relativos aos direitos sociais, a empresa contemporânea deve temperar sua busca pela lucratividade, ainda que seu objetivo fundamental seja o lucro ${ }^{20}$, pautando linha de atuação em ambiente de intensa colaboração com a sociedade; é condição de sobrevivência. Trata-se da função social da empresa ${ }^{21}$, de quem se espera que gere empregos, produza bens e serviços, recolha tributos e comprometa-se com uma agenda ambiental, tornando-se, também, agente de internalização de externalidades negativas, pelas quais muitas vezes é responsável.

O pleno desenvolvimento da empresa demanda, por sua vez, ambiente regulado de modo eficaz, com baixo custo de conformidade e com ampla deferência para com a segurança jurídica e para com o cumprimento dos contratos. O fim da empresa, além do lucro do empresário, é, também, a pessoa humana que nela trabalha, ou que dela compra, ou que dela depende, ou que para ela fornece, ou que a ela fiscaliza, deve o modelo propiciar meios para que esses fins possam ser alcançados. Analogicamente, a pessoa humana tem o direito potestativo de perseguir fins, como o bem-estar ou a felicidade e por isso é dotada de direitos fundamentais, que radicam, em sua dignidade intrínseca, deve a empresa (que é uma pessoa moral, coletiva ou jurídica), também, titularizar esses direitos, ou parcela deles, pelas mesmas razões, ainda que por via oblíqua. É este o tema do presente ensaio.

Com esse objetivo iniciamos com um esforço de síntese conceitual sobre a pessoa jurídica, que é o arranjo institucional em torno do qual se organiza uma empresa. Em seguida, buscamos um conceito contemporâneo de empresa, a partir de Alberto Asquini, e nos termos do atual Código Civil e do Projeto de

13 Por todos, firme na tese de que a Economia é que informa o direito, sob a ótica do pragmatismo norte-americano. POSNER, Richard. The problems of jurisprudence. Cambridge: Harvard University Press, 1993.

14 BRASIL. Constituição (1988). Constituição da República Federativa do Brasil. Disponível em: < http://www.planalto.gov.br/ccivil_03/Constituicao/Constituicao.htm>. Acesso em: 14 nov. 2016.

15 Assunto explorado, entre outros, por SUNSTEIN, Cass R. Free markets and social justice. New York: Oxford University Press, 1997.

16 ZYLBERSZTAJN, Decio; SZTAJN, Rachel. Direito e economia: análise econômica do direito e organizações. Rio de Janeiro: Elsevier, 2005. p. xi.

17 BRASIL. Lei n. 10.406, de 10 de janeiro de 2002. Código Civil. Disponível em: <http://www.planalto.gov.br/ccivil_03/leis/2002/ L10406.htm>. Acesso em: 14 nov. 2016.

18 COMPARATO, Fábio Konder. Direito empresarial: estudos e pareceres. São Paulo: Saraiva, 1990. p. 35 e ss.

19 FORGIONI, Paula A. A evolução do direito comercial brasileiro: da mercancia ao mercado. São Paulo: Revista dos Tribunais, 2016. p. 134.

20 COELHO, Fábio Ulhoa. Manual de direito comercial: direito de empresa. São Paulo: Revista dos Tribunais, 2016 . p. 43.

21 LOPES, Ana Frazão de Azevedo. Empresa e propriedade: função social e abuso de poder econômico. São Paulo: Quartier Latin, 2006. 
Novo Código Comercial que se discute no Congresso Nacional. No próximo passo, identificamos a agenda da dogmática dos direitos fundamentais, com foco na explicitação de quais poderiam de fato ser aplicados à atividade empresarial, a exemplo da liberdade de expressão comercial.

Concomitantemente, apresentamos uma rápida síntese do problema no direito comparado, exemplificativamente, e com muita concisão, em Portugal, na Alemanha e nos Estados Unidos. Apresentamos a questão na doutrina brasileira e, por fim, antes da sinopse conclusiva, identificamos algumas decisões do Supremo Tribunal Federal, que, de algum modo, problematizam as premissas com as quais trabalhamos.

Entendemos que as empresas são essenciais para a efetivação de direitos sociais e que, por isso, devem ser instrumentalizadas para melhor perseguirem seus fins. Uma forma de se efetivar essa instrumentalização é a garantia de titularidade de direitos fundamentais, levando-se em conta, contudo, algumas impossibilidades intrínsecas, decorrentes da própria natureza das pessoas morais ou coletivas.

\section{A PESSOA JURÍDICA E A EMPRESA NO DIREITO BRASILEIRO}

Disposições sobre as pessoas jurídicas estão fixadas na Parte Geral do Código Civil, no Livro referente às pessoas, em título próprio. Define-se que as pessoas jurídicas são de direito público, interno ou externo, e de direito privado ${ }^{22}$. Na construção do pensamento jurídico brasileiro, em obra originariamente publicada no século XIX, definiu-se pessoa jurídica como segue, com respectivas alterações ortográficas:

O sujeito de direitos, ou o ente capaz de adquirir e exercer direitos, é a pessoa. Mas a pessoa pode ser criada pela natureza ou pela lei. Daí vem a sua classificação em duas ordens: I - as pessoas naturais; II - as pessoas jurídicas. As primeiras os jurisconsultos também costumam denominar físicas, ou individuais, e Ulpiano as chamava singularis persona, por oposição a populus, cúria, colegium corpus. As segundas igualmente se denominam morais, abstratas, fictícias ou civis. ${ }^{23}$

Para os efeitos do presente trabalho, o interesse recai sobre as pessoas jurídicas de direito privado ${ }^{24}$, que detêm capital próprio e atuam no ambiente da iniciativa privada. A empresa, enquanto pessoa jurídica de direito privado, é parte de um esquema organizacional que sustenta conteúdos operacionais de livre concorrência, de propriedade privada e de sua função social, enquanto atributos da ordem econômica determinada pela Constituição $0^{25}$.

Assuntos como livre iniciativa e ordem econômica, que são centrais para a compreensão da inserção institucional das empresas, foram debatidos intensamente no Supremo Tribunal Federal, entre outros, quando se discutiu o tema da meia-entrada, em favor de estudantes de primeiro, segundo e terceiro graus. Naquela ocasião entendeu-se que a livre iniciativa não seria titulada apenas pela empresa, mas também pelo trabalho, ambiente no qual algum dissenso deveria ser composto à luz do interesse da coletividade ${ }^{26}$.

22 BRASIL. Lein. 10.406, de 10 de janeiro de 2002. Código Civil. Disponível em: <http://www.planalto.gov.br/ccivil_03/leis/2002/ L10406.htm>. Acesso em: 14 nov. 2016.

23 RIBAS, Joaquim. Direito civil brasileiro. Rio de Janeiro: Rio, 1977. p. 265.

24 Ainda que essas, bem entendido, também ser a forma organizacional e estrutural de pessoas jurídicas que ordinariamente seriam de direito público. Ver parágrafo único do art. 41 do Código Civil de 2002.

25 BRASIL. Constituição (1988). Constituição da República Federativa do Brasil. Disponível em: < http://www.planalto.gov.br/ccivil_03/Constituicao/Constituicao.htm>. Acesso em: 14 nov. 2016.

26 BRASIL. Supremo Tribunal Federal. Ação Direta de Inconstitucionalidade. ADI 1950/SP. Tribunal Pleno. Relator: Min. Eros Grau. Brasília, 3 de novembro de 2015. Disponível em: <http://stf.jusbrasil.com.br/jurisprudencia/762633/acao-direta-de-inconstitucionalidade-adi-1950-sp>. Acesso em: 14 nov. 2016. Ementa: "Ação Direta de Inconstitucionalidade. Lei n. 7.844/92, do Estado de São Paulo. Meia entrada assegurada aos estudantes regularmente matriculados em estabelecimentos de ensino. Ingresso em casas de diversão, esporte, cultura e lazer. Competência concorrente entre a União, Estados-membros e o Distrito Federal para legislar sobre direito econômico. Constitucionalidade. Livre iniciativa e ordem econômica. mercado. Intervenção do Estado na economia. Artigos $1^{\circ}$, $3^{\circ}, 170,205,208,215$ E 217, \ $3^{\circ}$, da Constituição do Brasil. 1. É certo que a ordem econômica na Constituição de 1.988 define opção por um sistema no qual joga um papel primordial a livre iniciativa. Essa circunstância não legitima, no entanto, a assertiva de que o Es- 
A ordem civil contempla pessoas jurídicas de direito privado organizadas em forma de associações, de sociedades, de fundações, de organizações religiosas, de partidos políticos, bem como as empresas individuais de responsabilidade limitada ${ }^{27}$. A existência legal dessas pessoas inicia-se com a inscrição do ato constitutivo no respectivo registro, precedida, quando necessário, de autorização ou aprovação do Poder Executivo, averbando-se no registro ${ }^{28}$ todas as alterações por que passar o ato constitutivo ${ }^{29}$.

O direito brasileiro contemporâneo mitigou o dogma da responsabilidade limitada do sócio $^{30}$, especialmente se comprovados o abuso da personalidade jurídica, caracterizado pelo desvio de finalidade, ou pela confusão patrimonial ${ }^{31}$. Nesses casos, dispõe o Código Civil, que:

Pode o juiz decidir, a requerimento da parte, ou do Ministério Público quando lhe couber intervir no processo, que os efeitos de certas e determinadas relações de obrigações sejam estendidos aos bens particulares dos administradores ou sócios da pessoa jurídica. ${ }^{32}$

Por fim e o que mais importa no presente trabalho, dispôs-se que se aplica às pessoas jurídicas, no que couber, a proteção dos direitos da personalidade ${ }^{33}$.

Deve-se definir, com alguma precisão, a amplitude da titularidade de direitos, por parte das pessoas jurídicas, porquanto não há dúvidas ou dissensos quanto a aspectos obrigacionais, resolvidos inclusive com a responsabilização do sócio, como anotamos no parágrafo anterior. Percebe-se na construção do conceito, ainda no século XIX, alguma visão realista, no sentido de que há prerrogativas que simplesmente não podem ser de titularidade de pessoas não naturais: a lei é o limite de reconhecimento e de atribuição de direitos, na hipótese das pessoas fictícias. Seguimos como Conselheiro Ribas, e mais uma vez com as adaptações ortográficas necessárias:

A pessoalidade natural é um fato independente da lei, e que lhe é imposto; fato que ela apenas reconhece e regula [...] A pessoalidade jurídica, pelo contrário, somente existe em virtude de lei; mas esta, criando-a, não pode dotá-la de plena capacidade de que as pessoas naturais são suscetíveis. Com efeito, a pessoalidade jurídica é essencialmente restrita; somente estende-se ao direito dos bens, e não pode compreender o de família, porquanto as relações de família pressupõem fatos realizados apenas por pessoas naturais, e tem a sua razão eficiente no destino do homem, da pessoa natural [...]..$^{34}$

tado só intervirá na economia em situações excepcionais. 2. Mais do que simples instrumento de governo, a nossa Constituição enuncia diretrizes, programas e fins a serem realizados pelo Estado e pela sociedade. Postula um plano de ação global normativo para o Estado e para a sociedade, informado pelos preceitos veiculados pelos seus artigos $1^{\circ}, 3^{\circ}$ e 170.3 . A livre iniciativa é expressão de liberdade titulada não apenas pela empresa, mas também pelo trabalho. Por isso a Constituição, ao contemplá-la, cogita também da "iniciativa do Estado"; não a privilegia, portanto, como bem pertinente apenas à empresa. 4. Se de um lado a Constituição assegura a livre iniciativa, de outro determina ao Estado a adoção de todas as providências tendentes a garantir o efetivo exercício do direito à educação, à cultura e ao desporto [artigos 23, inciso V, 205, 208, 215 e 217 \ $3^{\circ}$, da Constituição]. Na composição entre esses princípios e regras há de ser preservado o interesse da coletividade, interesse público primário. 5. O direito ao acesso à cultura, ao esporte e ao lazer, são meios de complementar a formação dos estudantes. 6. Ação direta de inconstitucionalidade julgada improcedente".

27 BRASIL. Lei n. 10.406, de 10 de janeiro de 2002. Código Civil. Disponível em: < http://www.planalto.gov.br/ccivil_03/leis/2002/ L10406.htm>. Acesso em: 14 nov. 2016.

28 O registro declarará: I - a denominação, os fins, a sede, o tempo de duração e o fundo social, quando houver; II - o nome e a individualização dos fundadores ou instituidores, e dos diretores; III - o modo por que se administra e representa, ativa e passivamente, judicial e extrajudicialmente; IV - se o ato constitutivo é reformável no tocante à administração, e de que modo; V - se os membros respondem, ou não, subsidiariamente, pelas obrigações sociais; VI - as condições de extinção da pessoa jurídica e o destino do seu patrimônio, nesse caso. BRASIL. Lei n 10.406, de 10 de janeiro de 2002. Código Civil. Disponível em: <http:/ / www.planalto. gov.br/ccivil_03/leis/2002/L10406.htm>. Acesso em: 14 nov. 2016.

29 BRASIL. Lei n. 10.406, de 10 de janeiro de 2002. Código Civil. Disponível em: <http://www.planalto.gov.br/ccivil_03/leis/2002/ L10406.htm>. Acesso em: 14 nov. 2016.

30 Assunto explorado por SALAMA, Bruno Meyerhof. O fim da responsabilidade limitada no Brasil: história, direito e economia. São Paulo: Malheiros, Fundação Getúlio Vargas, 2014.

31 BRASIL. Lei n. 10.406, de 10 de janeiro de 2002. Código Civil. Disponível em: <http://www.planalto.gov.br/ccivil_03/leis/2002/ L10406.htm>. Acesso em: 14 nov. 2016.

32 BRASIL. Lei n. 10.406, de 10 de janeiro de 2002. Código Civil. Disponível em: < http://www.planalto.gov.br/ccivil_03/leis/2002/ L10406.htm>. Acesso em: 14 nov. 2016.

33 BRASIL. Lei n. 10.406, de 10 de janeiro de 2002. Código Civil. Disponível em: < http://www.planalto.gov.br/ccivil_03/leis/2002/ L10406.htm>. Acesso em: 14 nov. 2016.

34 RIBAS, Joaquim. Direito civil brasileiro. Rio de Janeiro: Rio, 1977. p. 332. 
A pressuposição de que apenas fatos realizados por pessoas naturais justificam a titularidade de direitos, por parte de pessoas naturais, não reflete a também necessária compreensão de que pessoas jurídicas se prestam para realizar objetivos que se refletem nas pessoas naturais ${ }^{35}$. $\mathrm{Na}$ visão de um jurista típico de ambiente pré-capitalista, de sociedade agrária e escravista, monocultora e exportadora de commodities (como era o Brasil do século XIX), as pessoas jurídicas de direito privado se dividiam em corporações, subdivididas em pias $^{36}$, industriais e sodalícias; o reconhecimento da capacidade dessas pessoas jurídicas para que atuassem em juízo de alguma forma assinalava que se intuía a instrumentalidade desse arranjo organizacional:

A capacidade, concedida às pessoas jurídicas, de pouca eficácia seria, se elas não pudessem comparecer em juízo, para vindicar os direitos lesados ou defender-se de injustas pretensões alheias. Assim, é-lhes geralmente reconhecido o direito de comparecerem em juízo como autoras ou rés nas ações reais, ou pessoais, relativas a direitos ou bens, únicos para que foram instituídos ${ }^{37}$.

Na percepção de autor contemporâneo, tem-se o reconhecimento pleno dessa instrumentalidade da pessoa jurídica, especialmente com ênfase em recursos analógicos, nos sentido de que pessoas jurídicas realizam desejos e objetivos de pessoas humanas, o que, do ponto de vista lógico, pode encetar alguma tautologia:

A pessoa jurídica é [...] um conjunto de pessoas ou de bens, dotado de personalidade jurídica. Por analogia com as pessoas físicas a ordem jurídica disciplina o surgimento desses grupos, reconhecendoos como sujeitos de direito. Sua razão de ser está na necessidade ou conveniência de as pessoas naturais combinarem recursos de ordem pessoal ou material para a realização de objetivos comuns, que transcendem as possibilidades de cada um dos interessados por ultrapassarem o limite normal de sua existência ou exigirem a prática de atividades não exercitáveis por eles. Organizam-se, assim, de modo unitário, pessoas e bens, com o reconhecimento do direito que atribui personalidade ao conjunto que passa a participar da vida jurídica ${ }^{38}$.

Tem-se, dessa forma, insistência para com vínculos entre pessoas humanas e pessoas jurídicas, no sentido que essas últimas, apenas, instrumentalizam a ação daquelas primeiras. Isto é,

[...] enquanto a pessoa natural é o próprio homem, no exercício de suas atividades individuais, a pessoa jurídica é um grupo social, um aglomerado de homens, entre os quais se estabelece um vínculo de natureza diversa, conforme as finalidades que o grupo se propõe. ${ }^{39}$

A pessoa jurídica existe na medida em que permite que pessoas humanas desenvolvam suas atividades. Além de objetivos individuais, que se exaurem na existência da vida humana, há objetivos coletivos, que transcendem existências particularizadas e que se realizam nas pessoas jurídicas; estas - pessoas jurídicas - prestam-se para a realização de interesses coletivos e permanentes, razão pela qual são dotadas de personalidade ${ }^{40}$. A pessoa jurídica, resumindo, é “[...] ente incorpóreo que, como as pessoas físicas, pode ser sujeito de direitos”. ${ }^{41}$

A conceituação de empresa é tipologia normativa que se reporta ao Código Civil Italiano de 1942. Essa referência, em primeira vista, identificaria historicamente o conceito de empresa como arranjo institucional do fascismo.

35 A personalidade jurídica de uma sociedade, ponto de influxo concreto da atuação de uma pessoa jurídica, é percepção aceita no século XVIII, quando se admitiu a existência da persona ficta sine intellectualis. No entanto, a justificação da pessoa jurídica seguia conceitualmente desde o século XIII, com a teoria da ficção, que radicava no direito canônico, e que grande aceitação teve na Alemanha e na França. Savigny, no século XIX, impugnou essa ficção, firme no convencimento de que a vontade é característica do ser humano, e não de um ser artificial. Uma variável da doutrina ficcionista se desenvolveu na Alemanha, centrada na ideia de que uma pessoa jurídica é afetada existencialmente a seu patrimônio; é a doutrina do patrimônio-fim. As teorias da ficção foram superadas pelas teorias realistas, sobretudo a partir da doutrina organicista, difundida por Otto von Gierke. Nesse tema, por todos, ROSAS, João Grandino. Sociedade comercial e estado. São Paulo: Saraiva, 1995.

36 As corporações pias eram divididas em religiosas, beneficentes e literárias. As corporações religiosas eram dívidas em ordens monásticas, irmandades, confrarias e cabidos. RIBAS, Joaquim. Direito civil brasileiro. Rio de Janeiro: Rio, 1977. p. 343.

37 RIBAS, Joaquim, Direito civil brasileiro. Rio de Janeiro: Rio, 1977. p. 343.

38 AMARAL, Francisco. Direito civil: introdução. Rio de Janeiro: Renovar, 2014. p. 331-332.

39 DANTAS, Francisco San Tiago. Programa de direito civil. Rio de Janeiro: Estácio de Sá, 1977. p. 206.

40 É a lição de FERRARA, Francesco. Trattato di diritto civile italiano: dottrine generali. Roma: Athenaeum, 1921. v. 1. p. $597-598$.

41 MARTINS, Fran. Curso de direito comercial. Rio de Janeiro: Forense, 1967. p. 232. 
Toda percepção ideológica de empresa decorreria de categorias autoritárias, intervencionistas, orientadas para a realização de objetivos corporativistas. O Estado corporativo e o direito trabalhista de Mussolini que foram transpostos para a ordem normativa da Era de Vargas ${ }^{42}$ seriam, nessa linha de raciocínio, os pontos de convergência da definição de empresa. No Código Italiano, o ponto de partida do ordenamento comercial era o empreendedor, definido como aquele que exercitasse, profissionalmente, atividade econômica organizada com o objetivo da produção ou da troca de bens ou serviços ${ }^{43}$.

No entanto, argumenta-se, a definição e o modelo do Código Italiano de 1942 teriam se afastado dessas premissas políticas; há méritos técnicos na construção desse texto de lei, situação potencializada pelo processo de redemocratização que os italianos viveram a partir da queda de Mussolini ${ }^{44}$. Assim, e historicamente, empresa é organização de capital e de trabalho; presentemente deve se acrescer a inteligência aplicada (tecnologia), a organização e os insumos ${ }^{45}$; a empresa é, de qualquer modo, “[...] um dos componentes fundamentais da economia contemporânea, instrumento imprescindível para a realização das atividades mercantis e industriais em massa" ${ }^{" 46}$. Não se pode dissociar o conceito de empresa do conjunto tipológico dos atores econômicos e sociais contemporâneos.

$\mathrm{Na}$ formulação originariamente proposta por Alberto Asquini, a empresa se identificaria a partir de quatro perfis básicos: "o subjetivo (o empresário), o objetivo ou patrimonial (o estabelecimento), o funcional (a atividade) e o corporativo ou institucional (as relações trabalhistas)" "47. Asquini enfatizou a necessidade de se centrar a empresa na figura do empresário, cuja natureza e perfil defende que devessem ser melhores estudadas ${ }^{48}$.

No Brasil, a intuição de que o conceito de empresa, também, radica em regime de exceção é, de alguma forma, intrigante. Isto porque o projeto do novo Código Civil se relaciona a um convite feito em 1969 a Miguel Reale, por parte do então Ministro da Justiça do Governo Militar, Gama e Silva. A confecção, a discussão e a recepção do Código Civil de 2002, no entanto, qualificam um novo rumo. É expressivo que a livre iniciativa e a livre concorrência informam nova ordem econômica, sugerindo pontos de interpretação que devem ser compreendidos também no contexto da função social da propriedade ${ }^{49}$, o que sugere novo paradigma jurídico e institucional, que, inegavelmente, se afasta de formulação pretensamente autoritária.

Presentemente, o empresário é "quem exerce profissionalmente atividade econômica organizada para a produção ou a circulação de bens ou de serviços" ${ }^{50}$, excluindo-se quem exerça "[...] profissão intelectual, de natureza científica, literária ou artística, ainda com o concurso de auxiliares ou colaboradores, salvo se

42 As linhas ideológicas desse modelo, em sua versão brasileira, podem ser exploradas por VIANNA, Oliveira. Instituições Políticas Brasileiras. São Paulo: Universidade de São Paulo, Niterói: Universidade Federal Fluminense, 1987. FAORO, Raymundo. Os donos do poder: formação do patronato político brasileiro. São Paulo: Globo, 2001. p. 760 e ss. CAMPOS, Francisco. Antecipaçoes à reforma politica. Rio de Janeiro: José Olympio Editora, 1940 e CAMPOS, Francisco. Pareceres do consultor-geral da república. Rio de Janeiro: A. Coelho Branco Filho, 1952.

43 No original: Art. 2082 Imprenditore - E' imprenditore chi esercitaprofessionalmenteun'attivitàeconomicaorganizzata [...] al fine dellaproduzione o delloscambiodibeni o diservizi [...].

44 COELHO, Fábio Ulhoa. Manual de direito comercial: direito de empresa. São Paulo: Revista dos Tribunais, 2016. p. 33.

45 PANTOJA, Teresa Cristina G. Anotações sobre pessoas jurídicas. In: TEPEDINO, Gustavo (Org.). A parte geral do novo código civil. Rio de Janeiro: Renovar, 2003. p. 118.

46 AMARAL, Francisco. Direito civil: introdução. Rio de Janeiro: Renovar, 2014. p. 196.

47 ARNOLDI, Paulo Roberto Colombo. Teoria geral do direito comercial: introdução à teoria da empresa. São Paulo: Saraiva, 1998. p. 160. O texto seminal de Alberto Asquini, Profili dell'impresa, foi publicado no volume 41 da Rivista del Diritto Commerciale, em 1943, traduzido para o português por Fábio Konder Comparato e publicado na Revista de Direito Mercantil, Industrial, Econômico e Financeiro, n. 104. Isto é, o texto de Asquini foi traduzido para o português mais de 50 anos depois de originariamente publicado. ASQUINI, Alberto. Perfis da Empresa. Revista de Direito Mercantil, Industrial, Econômico e Financeiro, São paulo, v. 35, n. 104, p. 109-126, out./dez. 1966.

48 ASQUINI, Alberto. Perfis da Empresa. Revista de Direito Mercantil, Industrial, Econômico e Financeiro, São paulo, v. 35, n. 104, p. 109-126, out./dez. 1966. p. 125.

49 GRAU, Eros Roberto. A ordem econômica na constituicão de 1988. São Paulo: Malheiros, 2010.

50 BRASIL. Lei $n$. 10.406, de 10 de janeiro de 2002. Código Civil. Disponível em: < http://www.planalto.gov.br/ccivil_03/leis/2002/ L10406.htm>. Acesso em: 14 nov. 2016. 
o exercício da profissão constituir elemento de empresa" ${ }^{51}$.Deve-se ter em mente o sentido duplo que a palavra empresário carrega no Código Civil. Simultaneamente, é quem obtém registro na Junta Comercial, na qualidade de empresário; nesse caso, tem-se o empresário individual; bem como se refere à sociedade empresária, isto é, uma pessoa jurídica ${ }^{52}$.

A partir da fixação normativa do conceito de empresário, que se construiu uma compreensão doutrinária de empresa, no sentido de que,

A empresa é uma organização de pessoas, bens e atos voltada para a produção e circulação de mercadorias ou serviços destinados ao mercado, com o fim de lucro e sob a iniciativa e o comando de dado sujeito de direito, o empresário. ${ }^{53}$

A definição alcança, prioritariamente, a ideia de organiæ̧ação, aproximando pessoas (aspecto subjetivo), bens (aspecto objetivo) e atos (aspecto volitivo), com destino certo, o mercado e a busca do lucro (aspectos econômicos), sob o comando do empresário, que é quem enfrenta os riscos, suporta as perdas e contabiliza os ganhos (aspectos negociais).

Assim, o empresário, é o "[...] sujeito de direito [que] ostenta como características primordiais a iniciativa e o risco" ${ }^{54}$. Rigorosamente,

A empresa, em si mesma, não tem personalidade jurídica, de maneira que uma pessoa, o empresário, manifesta sua vontade e comanda toda a atividade empresarial, assumindo obrigações e auferindo créditos. ${ }^{55}$

Esse empresário individual, pessoa física, será a contrapartida de imaginário empresário coletivo ${ }^{56}$, pessoa jurídica, retomando-se e reafirmando-se a clássica dicotomia do direito brasileiro, cindido em pessoas físicas (naturais) e morais (jurídicas).

Transita na Câmara Federal um projeto de lei que dispõe sobre um novo Código Comercial ${ }^{57}$. No projeto não se contempla a acepção de empresa, definindo-seapenas o empresário, na tradição do Código Civil Italiano de 1942 e do Código Civil Brasileiro de 2002. Nesse sentido, empresário é a pessoa natural que explora profissionalmente uma empresa ou a sociedade que adote qualquer um dos tipos sociais regulados pelo Código ${ }^{58}$. Mencionado projeto de lei, também, cuida do registro público das empresas, dispõe sobre empresário individual, regula o exercício da empresa em regime fiduciário, bem como trata do estabelecimento empresarial. Ao invés da definição de empresa, optou-se pela fixação de um conceito de estabelecimento empresarial, isto é, na linguagem do projeto, "o complexo de bens organizado pelo empresário para a exploração da empresa" 59 .

Apresentadas as linhas gerais que identificam a pessoa jurídica e a empresa, seguimos com uma também sumária descrição da agenda dos direitos fundamentais e sua projeção na atividade empresarial, inclusive com referência ao direito estrangeiro.

51 BRASIL. Lein. 10.406, de 10 de janeiro de 2002. Código Civil. Disponível em: < http://www.planalto.gov.br/ccivil_03/leis/2002/ L10406.htm>. Acesso em: 14 nov. 2016.

52 MAMEDE, Gladston. Manual de direito empresarial. São Paulo: Atlas, 2006. p. 6.

53 BARBOSA FILHO, Marcelo Fortes. Comentários ao art. 966 do Código Civil. In: PELUSO, Cezar (Coord.). Código civil comentado. Barueri: Manole, 2010. p. 972.

54 BARBOSA FILHO, Marcelo Fortes. Comentários ao art. 966 do Código Civil. In: PELUSO, Cezar (Coord.). Código civil comentado. Barueri: Manole, 2010. p. 973.

55 BARBOSA FILHO, Marcelo Fortes. Comentários ao art. 966 do Código Civil. In: PELUSO, Cezar (Coord.). Código civil comentado. Barueri: Manole, 2010. p. 973.

56 BARBOSA FILHO, Marcelo Fortes. Comentários ao art. 966 do Código Civil. In: PELUSO, Cezar (Coord.). Código civil comentado. Barueri: Manole, 2010. p. 973.

57 BRASIL. Projeto de Lei n. 1.572 de 2011. Institui o Código Comercial. Disponível em: <http://www.camara.gov.br/proposicoesWeb/fichadetramitacao?idProposicao $=508884>$. Acesso em: 14 nov. 2016.

58 BRASIL. Projeto de Lei n. 1.572 de 2011. Institui o Código Comercial. Disponível em: <http://www.camara.gov.br/proposicoesWeb/fichadetramitacao?idProposicao=508884>. Acesso em: 14 nov. 2016.

59 BRASIL. Projeto de Lei n. 1.572 de 2011. Institui o Código Comercial. Disponível em: <http://www.camara.gov.br/proposicoesWeb/fichadetramitacao?idProposicao=508884>. Acesso em: 14 nov. 2016. 


\section{A dogmática DE DIREITOS FUNDAMENTAIS E A ATIVIDADE EMPRESARIAL}

Direitos fundamentais, em princípio, porque justificados pela dignidade da pessoa humana, seriam de titularidade apenas de pessoas humanas. Entre os vários marcos fundantes dessa premissa, por exemplo, e do ponto de vista de uma história muito recente, retoma-se, entre outros, o esforço alemão de reerguimento, sobremodo moral, ocorrido após o fim da segunda guerra mundial. No plano jurídico, esse esforço se desdobrou na construção de um texto constitucional (Grundgesetəafür die Bundesrepublik. Deutschland) e na atuação de um tribunal com funções de controle e monitoramento da então denominada Lei Fundamental.

Houve então forte influência dos países aliados que, então, ocupavam a Alemanha Ocidental, e que apostavam no processo de reunificação como contrapeso à influência soviética no contexto geopolítico europeu. A dogmática dos direitos fundamentais é, também, marcada pela atuação do Tribunal Constitucional Federal da Alemanha, que exerce preponderante influência em várias cortes constitucionais (a exemplo do Brasil, de Portugal, da Itália, da Espanha e da Colômbia), bem como nas concepções doutrinárias de alguns constitucionalistas brasileiros ${ }^{60}$, que estudaram na Alemanha. De alguma maneira, retomou-se o filogermanismo da Escola do Recife, emblemático em autores como Silvio Romero, Tobias Barreto e Clóvis Bevilácqua, ainda que, naturalmente, em outro contexto, por outras razões, e em dinâmica de influência absolutamente distinta.

A construção do texto da Lei Fundamental alemã se deu em ambiente histórico marcado por intensa complexidade, no qual os aliados vitoriosos formularam várias estratégias para a resolução de um problema alemão. A oposição entre os comandos da zona soviética e das áreas de ocupação ocidental, com a consequente emergência de duas Alemanhas, bem como o subsequente contexto da guerra fria, são indicativos de um ambiente marcado pela insegurança institucional, que influenciou fortemente os autores da Lei Fundamental. O agente definidor da reação civilizatória se desdobrou na construção do texto constitucional alemão de 23 de maio de 1949 e na criação de um tribunal defensor do núcleo e do vetor desse texto constitucional: "Die Würdedes Menschenistunantasbar", isto é, "a dignidade da pessoa humana é inviolável".

O Tribunal Constitucional Federal, bem como a doutrina juspublicista alemã do pós-guerra, podem qualificar arranjos institucionais e conceituais que de algum modo resgatam o legado civilizatório da tradição alemã, absolutamente contestado por conta da barbárie que caracterizou a era nacional-socialista. Assim, à concepção clássica de era dos direitos ${ }^{61}$, pode-se acrescentar ingrediente histórico que nos indica acidente e desvio de rota, corrigidos pela jurisprudência e por um texto constitucional.

Não é essa, no entanto, a única trajetória de afirmação do conceito de dignidade da pessoa humana ${ }^{62}$. O curso e o movimento da afirmação dos direitos fundamentais é produto histórico também de várias outras experiências, entre as quais se aponta a experiência histórica brasileira, na qual, "o preço da liberdade passou a ser a eterna resistência, cidadela da lucidez sitiada por um poder que se abastilhara, absoluto e avassalante" ${ }^{93}$. A centralidade dos direitos na figura humana propriamente dita, também decorre da,

[...] revelação de que todos os seres humanos, apesar das inúmeras diferenças biológicas e culturais que os distinguem entre si, merecem igual respeito, como únicos entes no mundo capazes de amar, descobrir a verdade e criar a beleza. ${ }^{64}$

60 MENDES, Gilmar Ferreira. Estado de direito e jurisdição constitucional. São Paulo: Saraiva, 2011.; NEVES, Marcelo. A constitucionalização simbólica. São Paulo: Martins Fontes, 2013.; NEVES, Marcelo. Transconstitucionalismo. São Paulo: Martins Fontes, 2012.; SARLET, Ingo Wolfgang. A eficácia dos direitos fundamentais: uma teoria dos direitos fundamentais na perspectiva constitucional. Porto Alegre: Livraria do Advogado Editora, 2015.; SILVA, Virgílio Afonso. Direitos Fundamentais. São Paulo: Malheiros, 2009.

61 BOBBIO, Norberto. A era dos direitos. Rio de Janeiro: Elsevier, 2004.

62 Para uma síntese de exploração dessa trajetória, conferir, SARMENTO, Daniel. Dignidade da pessoa bumana: conteúdo, trajetórias, metodologia. Belo Horizonte: Fórum, 2016. Para uma compilação e exploração dos textos fundantes dos direitos humanos: COMPARATO, Fábio Konder. A afirmação histórica dos direitos bumanos. São Paulo: Saraiva, 2005.

63 BARROSO, Luís Roberto. Direito constitucional brasileiro: o problema da federação. Rio de Janeiro: Forense, 1982. p. xii.

64 COMPARATO, Fábio Konder. A afirmação bistórica dos direitos bumanos. São Paulo: Saraiva, 2005. p. 1. 
Esse reconhecimento, isto é,

Essa importância atribuída à dignidade da pessoa humana no Brasil e no constitucionalismo global deve ser saudada como sinal de avanço civilizatório [...] trata-se de princípio profundamente humanista, baseado na valorização da pessoa e comprometido com a garantia dos seus direitos básicos contra todas as formas de injustiça e opressão [...]. ${ }^{65}$

Fixa-se, assim, um constitucionalismo moralmente reflexivo ${ }^{66}$, centrado, evidentemente, na pessoa humana.

A pessoa jurídica, e não há outra forma de entendê-la nesse tema, é arranjo institucional que tem por finalidade atender a necessidades humanas. A pessoa jurídica não tem essência distinta, independente, a ponto de não necessitar da pessoa humana para concretamente existir. Pessoas jurídicas somente existem porque há pessoas humanas. Essa obviedade, também, se traduz na admissão de que pessoas jurídicas sejam detentoras de direitos fundamentais, exatamente, e na medida, em que são expressões da existência das pessoas humanas. Desse modo:

Em rigor, só os indivíduos poderiam ser titulares (sujeitos ativos) de direitos fundamentais, pois a dignidade humana que os fundamenta só vale para as pessoas físicas (as únicas pessoas humanas) e não para as pessoas jurídicas ou coletivas. Porém, apontam-se algumas compressões ou mesmo limitações em relação a este elemento, que resultariam da existência dos direitos de exercício coletivo e, sobretudo, da titularidade de direitos fundamentais por pessoas coletivas ${ }^{67}$.

Deve-se, assim, aferir-se, nos vários casos concretos, se o exercício dessa titularidade seria, efetivamente, possível. Precisa-se averiguar como efetivamente pessoas jurídicas exerceriam direitos civis e políticos (liberdades de locomoção, de crença religiosa, de expressão, de voto, de profissão), direitos econômicos, sociais e culturais (direitos trabalhistas, previdenciários, de saúde, à educação) ou direitos difusos (meio ambiente, paz, desenvolvimento, direito ao patrimônio comum da humanidade $)^{68}$.Essa é a conclusão que se ampara, inclusive, com recorrente referência doutrinária. Nesse sentido:

[...] recepcionada pelo direito brasileiro a tese de que as pessoas jurídicas, ao contrário das pessoas naturais (físicas ou singulares) não são titulares de todos os direitos, mas apenas daqueles direitos que lhes são aplicáveis por serem compatíveis com a sua natureza peculiar de pessoa jurídica, além de relacionados aos fins da pessoa jurídica, o que, todavia, há de ser verificado caso a caso. Neste particular, também ao direito constitucional brasileiro é aplicável, [...] a lição de Jorge Miranda, no sentido da inexistência de uma equiparação entre pessoas jurídicas e naturais, visto que se trata, em verdade, de uma espécie de cláusula (no caso brasileiro, de uma cláusula implícita) de limitação, designadamente de limitação da titularidade aos direitos compatíveis com a condição de pessoa jurídica ${ }^{69}$.

Os limites que há para que pessoas jurídicas exerçam os direitos fundamentais em sua plenitude decorrem de sua inexistência biológica ${ }^{70}$, isto é, "se as pessoas jurídicas têm direito à privacidade, à ampla defesa e à propriedade, por exemplo, por óbvio não tem direito à saúde" ${ }^{\text {"71 }}$. É essa, por exemplo, a lógica da Constituição de Portugal, que, na parte referente aos direitos e deveres fundamentais, em passagem sobre o princípio da universalidade, relativo aos cidadãos, também dispõe que "as pessoas coletivas gozam dos direitos e estão sujeitas aos deveres compatíveis com a sua natureza" ${ }^{72}$. A concepção de universalidade, nesse contexto, remete o intérprete a um liame de subjetividade, que vincula pessoas físicas (humanas) e pessoas jurídicas (empresas, para os efeitos do presente estudo).

65 SARMENTO, Daniel. Dignidade da pessoa humana: conteúdo, trajetórias, metodologia. Belo Horizonte: Fórum, 2016. p. 15.

66 CANOTILHO, J. J. Gomes. "Brancosos" e interconstitucionalidade: itinerário dos discursos sobre a historicidade constitucional. Coimbra: Almedina, 2006. p. 101 e ss.

67 ANDRADE, José Carlos Vieira de. Os direitos fundamentais na constituição portuguesa de 1976. Coimbra: Almedina, 2006. p. 123.

68 Para uma análise dessas tipologias: ROTHENBURG, Walter Claudius. Direitos fundamentais. Rio de Janeiro: Forense, 2014.

69 SARLET, Ingo Wolfgang. A eficácia dos direitos fundamentais: uma teoria dos direitos fundamentais na perspectiva constitucional. Porto Alegre: Livraria do Advogado Editora, 2015. p. 230.

70 ROTHENBURG, Walter Claudius. Direitos fundamentais. Rio de Janeiro: Forense, 2014. p. 58.

71 ROTHENBURG, Walter Claudius. Direitos fundamentais. Rio de Janeiro: Forense, 2014. p. 59.

72 PORTUGAL. Constituição da República Portuguesa. Disponível em: <http://www.parlamento.pt/Legislacao/Paginas/ConstituicaoRepublicaPortuguesa.aspx>. Acesso em: 14 nov. 2016. 
De igual modo, essa é a fórmula utilizada pela Constituição da Alemanha, que também dispõe que "os direitos fundamentais também são válidos para as pessoas jurídicas sediadas no país, conquanto, pela sua essência, sejam aplicáveis às mesmas" ${ }^{\text {73 }}$. A pessoa jurídica e, no presente caso, a empresa, é figura dominante da economia capitalista, pelo que excluí-la da possibilidade da titularidade de direitos fundamentais revela algum contrasenso. Por uma questão de absoluta incompatibilidade fática, das pessoas jurídicas, devem-se excluir, "[...] os direitos estritamente pessoais, os direitos políticos principais e os direitos sociais, que são inseparáveis da personalidade singular" ${ }^{\text {”74 }}$. Pode-se apresentar um balanço da situação, como segue:

[...] as pessoas jurídicas são equiparadas às físicas, desde que o exercício de um direito seja compatível com as peculiaridades estruturais da pessoa jurídica e, principalmente, com a sua inexistência biológica. Não se pode pensar que uma pessoa jurídica venha a exigir a proteção de sua integridade corporal ou pedir o pagamento de um salário-mínimo e o oferecimento de oportunidades de lazer. Mas não há óbice para que a pessoa jurídica possa exercer o direito de propriedade ou de reivindicar o sigilo de correspondência ${ }^{75}$.

Afirma-se um caráter final da personalidade jurídica do homem e um caráter instrumental da personalidade jurídica da pessoa moral ou coletiva ${ }^{76}$, também porque:

[...] as pessoas coletivas privadas são construções dos homens indispensáveis à sua atuação nos diversos domínios da vida, de modo que o livre desenvolvimento da personalidade [...] depende de uma complexa rede de relações sociais e econômicas, que se processam em grande medida através dessas construções humanas. ${ }^{77}$

Desse modo, a ofensa à titularidade de direitos fundamentais da pessoa jurídica é uma afronta também direta às pessoas humanas, porquanto essas últimas partilham direitos com aquela primeira, que os instrumentaliza. Trata-se de um "alargamento teleológico" da previsão constitucional (portuguesa) que imputa direitos e deveres a pessoas humanas ${ }^{78}$.

Insistimos que esse "alargamento teleológico" deva ser substancializado, sobremodo jurisprudencialmente. A influência dos direitos fundamentais sobre o comportamento dos sujeitos de direito privado ${ }^{79}$ não se resume na construção de uma agenda estatal não interventiva. Pode-se fortalecer a empresa, em sua esfera de atuação, justamente para que o escopo de obtenção do lucro e efetivação de direitos sociais possa ser estabilizado por uma conjunção de fatores, que realizem premissas constitucionais de promoção da dignidade da pessoa humana. É desse aspecto jurisprudencial que tratamos em seguida.

\section{A Jurisprudência do Supremo Tribunal Federal em tema de direitos fundamentais E PESSOAS JURÍDICAS}

Ao que consta, o STF, ainda, não foi questionado, diretamente, a respeito da titularidade de direitos fundamentais, por parte de pessoas jurídicas. Há súmula de jurisprudência aprovada em 13 de dezembro de 1963, que fixou, em forma de verbete, que pessoa jurídica não tem legitimidade para propor ação popular. Não se cogitaria, assim, de uma empresa propondo a mencionada ação, o que de plano evidencia tradição jurisprudencial de limitação de prerrogativas de pessoas jurídicas. Mais recentemente, há conjunto de decisões

73 ALEMANHA. Constituição da Alemanha. Disponível em: <https://www.btg-bestellservice.de/pdf/80208000.pdf>. Acesso em: 14 nov. 2016.

74 ANDRADE, José Carlos Vieira de. Os direitos fundamentais na constituição portuguesa de 1976. Coimbra: Almedina, 2006. p. 125.

75 DIMOULIS, Dimitri; MARTINS, Leonardo. Teoria geral dos direitos fundamentais. São Paulo: Revista dos Tribunais, 2007 . p. 97.

76 ANDRADE, José Carlos Vieira de. Os direitos fundamentais na constituição portuguesa de 1976. Coimbra: Almedina, 2006. p. 126.

77 ANDRADE, José Carlos Vieira de. Os direitos fundamentais na constituição portuguesa de 1976. Coimbra: Almedina, 2006. p. 127.

78 Para esse conceito de "alargamento teleológico" conferir: CANOTILHO, J. J. Gomes. Direito constitucional. Coimbra: Almedina, 1993. p. 558 e ss.

79 Nesse tema, por todos: CANARIS, Claus-Wilhelm. Direitos fundamentais e direito privado. Coimbra: Almedina, 2006. p. 52 e ss. 
nas quais o assunto é por vezes central, e por vezes periférico. Nesse contexto, o tema emergiu, basicamente, em quatro situações, de peculiaridade diversa.

A relação entre direitos fundamentais e pessoas jurídicas foi tratada, entre outros, i) em habeas corpus que tinha como pano de fundo a prerrogativa do uso do remédio, por parte de empresas ${ }^{80}$, ii) em agravo regimental que cuidava da possibilidade do uso de assistência judiciária gratuita, também por parte de pessoas morais ${ }^{81}$, iii) em mandado de injunção no qual Município enfrentava o Congresso Nacional ${ }^{82}$ e iv) em ação direta de inconstitucionalidade na qual se discutiu, entre vários tópicos, a possibilidade de pessoas jurídicas financiarem campanhas eleitorais ${ }^{83}$. São assuntos distintos, nos quais há, de fato, uma sutil convergência de problemas jurídicos.

Pode-se especular de uma construção de precedentes ${ }^{84}$, com indicação de uma ratiodecidendi que poderia informar e pautar discussões presentes e futuras. Nesse sentido, há indicativos de que o STF corrobora essa titularidade, mitigada, no entanto, inclusive de pessoa jurídica de direito público, como se indicará, ainda, que com limites bem definidos. Exemplifica-se com a impossibilidade do financiamento de campanhas políticas por parte de pessoas jurídicas, em contexto discursivo que pode suscitar o tema da liberdade de expressão, a exemplo do que ocorreu na jurisprudência dos Estados Unidos da América ${ }^{85}$, não obstante o fato de que a solução dada pela Suprema Corte norte-americana tenha sido diferente em relação à solução dada pelo STF.

Iniciamos com discussão interessante que se deu na situação da responsabilização penal da pessoa jurídica em matéria de crime ambiental. Ainda que se tenha disposição constitucional expressa ${ }^{86}$, relativa à mencionada responsabilização, a casuística nos revela questões inusitadas e inesperadas. Nesse primeiro caso, basicamente, questionou-se se uma empresa detinha prerrogativa para impetrar habeas corpus com objetivo de trancamento de ação penal em matéria de responsabilização por crime ambiental ${ }^{87}$.

No pano de fundo da discussão o fato da empresa interessada ter celebrado (e ao que parece, cumprido) um termo de ajuste de conduta-TAC com o Ministério Público Estadual, sendo que, mais tarde, a empresa fora denunciada, pelos mesmos fatos, pelo Ministério Público Federal. Do ponto de vista da dogmática

80 BRASIL. Supremo Tribunal Federal. Habeas Corpus. HC 92.921-4-BA. Primeira turma. Relator: Ministro Ricardo Lewandowski. Brasília, 19 de agosto de 2008. Disponível em: <http://stf.jusbrasil.com.br/jurisprudencia/14719240/habeas-corpus-hc92921-ba>. Acesso em: 19 nov. 2016.

81 BRASIL. Supremo Tribunal Federal. Agravo Regimental nos Embargos de Declaração na Reclamação. AgREDRCL 1.905-5/ SP. Tribunal Pleno. Relator: Ministro Marco Aurélio. Brasília, 15 de agosto de 2002. Disponível em: < http:// redir.stf.jus.br/paginadorpub/paginador.jsp?docTP=AC\&docID=347936>. Acesso em: 19 nov. 2016.

82 BRASIL. Supremo Tribunal Federal. Mandado de Injunção. MI 725-0/RO. Tribunal Pleno. Relator: Ministro Gilmar Mendes. Brasília, 10 de maio de 2007. Disponível em: <http://stf.jusbrasil.com.br/jurisprudencia/757310/mandado-de-injuncao-mi725-ro>. Acesso em: 19 nov. 2016.

83 BRASIL. Supremo Tribunal Federal. Ação Direta de Inconstitucionalidade. ADI 4.650/DF. Plenário. Relator: Ministro Luiz Fux. Brasília, 17 de setembro de 2015. Disponível em: <http://redir.stf.jus.br/paginadorpub/paginador. jsp?doc'TP=TP\&docID=10329542> . Acesso em: 20 nov. 2016.

84 Para a metodologia do precedente, seus problemas e dilemas inerentes: MELLO, Patrícia Perrone. Precedentes: o desenvolvimento judicial do direito no constitucionalismo contemporâneo. Rio de Janeiro: Renovar, 2008. Na doutrina norte-americana, conferir: GERHARDT, Michael J. The power of precedent. New York: Oxford University Press, 2008. HANSFORD, Thomas G.; SPRIGGS II, James F. The politics of precedent on the U.S. supreme court. Princeton, Oxford: Princeton University Press, 2006.

85 A legislação sobre o financiamento das campanhas suscitou várias discussões e alcançou diversas vezes a Suprema Corte dos Estados Unidos. Houve uma acomodação judicial desses problemas, no contexto da discussão de alguns casos, que fixaram os novos padrões. Entre esses casos, as discussões em McConnell v. FEC (2003), Citizens United v. FEC (2008) e McCutcheon v. FEC (2014). A esses casos deve-se acrescentar uma discussão importantíssima ocorrida em Buckley v. Valeo (1976). Nesse sentido, a matéria não é de exclusiva definição normativa. Vige a regra do precedente, e por consequência toda a lógica que lhe é própria.

86 As condutas e atividades consideradas lesivas ao meio ambiente sujeitarão os infratores, pessoas físicas ou jurídicas, as sanções penais e administrativas, independentemente da obrigação de reparar os danos causados. BRASIL. Constituição (1988). Constituição da República Federativa do Brasil. Disponível em: <http://www.planalto.gov.br/ccivil_03/Constituicao/Constituicao.htm>. Acesso em: 14 nov. 2016.

87 BRASIL. Supremo Tribunal Federal. Habeas Corpus. HC 92.921-4-BA. Primeira turma. Relator: Ministro Ricardo Lewandowski. Brasília, 19 de agosto de 2008. Disponível em: <http://stf.jusbrasil.com.br/jurisprudencia/14719240/habeas-corpus-hc92921-ba>. Acesso em: 19 nov. 2016. 
constitucional e penal, discutia-se a doutrina da dupla imputação, que vincula, pelo mesmo fato, a pessoa jurídica e seus correspondentes responsáveis, pessoas físicas ${ }^{88}$. Nos dizeres do Ministro Relator,

A dupla imputação [...] importa em reconhecer que [...] pessoas jurídicas e naturais farão, conjuntamente, parte do polo passivo da ação penal, de modo que o habeas corpus, que discute a viabilidade do prosseguimento da ação penal, reflete diretamente na liberdade destas últimas. ${ }^{89}$

É a solução prática que se tem para a responsabilização penal das pessoas jurídicas.

O Ministério Público havia levantado preliminar, relativa à possibilidade do manejo do writ por pessoa jurídica, que foi rejeitada pelo Ministro Relator. O Ministro Marco Aurélio reconheceu, em seu voto, que:

[...] podemos ter apenação quanto à pessoa jurídica, em se tratando de crime contra o meio ambiente, quer sob o ângulo da interdição da atividade desenvolvida, quer sob o ângulo da multa. ${ }^{90}$

Essa decisão revela ângulo pragmático de conformação de titularidade de direitos e deveres, quanto às pessoas jurídicas. Ressaltou, no entanto, que "é impossível prender-se, cercear-se a liberdade de ir e vir da pessoa jurídica [...] sempre há de estar envolvida uma pessoa natural"'11. E forte nesse aspecto prático, de que não há como se prender a pessoa jurídica, é que decidiu que a "pessoa jurídica não pode figurar como paciente" ${ }^{92}$, justamente porque o habeas corpus se prestaria para garantir liberdade de ir e vir" ${ }^{93}$.

Esse argumento foi, também, enfatizado pelo Ministro Relator, para quem:

Pessoas jurídicas respondem penalmente em especial considerada a lei do meio ambiente [...] só não dispõe, para defender-se, do habeas corpus, porque jamais estará em jogo a liberdade de ir e vir da pessoa jurídica como tal. ${ }^{94}$

O Ministro Menezes Direito não conheceu do habeas corpus com relação à pessoa jurídica, núcleo da discussão, em seu aspecto processual. Argumentou que se assim procedesse, necessitaríamos de uma nova doutrina do habeas corpus. Seguiríamos caminho diverso do trilhado por Rui Barbosa, um dos construtores desse conceito ${ }^{95}$.

A Ministra Cármen Lúcia, também, vinculou a possibilidade do habeas exclusivamente às pessoas humanas, dado que a liberdade, enquanto conceito e pressuposto, não se realizaria na pessoa jurídica, "porque a liberdade é parte animal do ser humano, ou seja, é uma paixão ou sentimento que não tem muita explicação

88 Nesse assunto, por todos, SHECAIRA, Sérgio Salomão. Responsabilidade penal da pessoa jurídica. São Paulo: Método, 2003.

89 BRASIL. Supremo Tribunal Federal. Habeas Corpus. HC 92.921-4-BA. Primeira turma. Relator: Ministro Ricardo Lewandowski. Brasília, 19 de agosto de 2008. Disponível em: <http://stf.jusbrasil.com.br/jurisprudencia/14719240/habeas-corpus-hc92921-ba>. Acesso em: 19 nov. 2016.

90 BRASIL. Supremo Tribunal Federal. Habeas Corpus. HC 92.921-4-BA. Primeira turma. Relator: Ministro Ricardo Lewandowski. Brasília, 19 de agosto de 2008. Disponível em: <http://stf.jusbrasil.com.br/jurisprudencia/14719240/habeas-corpus-hc92921-ba>. Acesso em: 19 nov. 2016.

91 BRASIL. Supremo Tribunal Federal. Habeas Corpus. HC 92.921-4-BA. Primeira turma. Relator: Ministro Ricardo Lewandowski. Brasília, 19 de agosto de 2008. Disponível em: <http://stf.jusbrasil.com.br/jurisprudencia/14719240/habeas-corpus-hc92921-ba>. Acesso em: 19 nov. 2016.

92 BRASIL. Supremo Tribunal Federal. Habeas Corpus. HC 92.921-4-BA. Primeira turma. Relator: Ministro Ricardo Lewandowski. Brasília, 19 de agosto de 2008. Disponível em: <http://stf.jusbrasil.com.br/jurisprudencia/14719240/habeas-corpus-hc92921-ba>. Acesso em: 19 nov. 2016.

93 Ao longo do debate, sustentando esse argumento, o Ministro Marco Aurélio observou que "a pessoa jurídica jamais parará no xilindró”. BRASIL. Supremo Tribunal Federal. Habeas Corpus. HC 92.921-4-BA. Primeira turma. Relator: Ministro Ricardo Lewandowski. Brasília, 19 de agosto de 2008. Disponível em: <http://stf.jusbrasil.com.br/jurisprudencia/14719240/habeas-corpushc-92921-ba>. Acesso em: 19 nov. 2016.

94 BRASIL. Supremo Tribunal Federal. Habeas Corpus. HC 92.921-4-BA. Primeira turma. Relator: Ministro Ricardo Lewandowski. Brasília, 19 de agosto de 2008. Disponível em: <http://stf.jusbrasil.com.br/jurisprudencia/14719240/habeas-corpus-hc92921-ba>. Acesso em: 19 nov. 2016.

95 BRASIL. Supremo Tribunal Federal. Habeas Corpus. HC 92.921-4-BA. Primeira turma. Relator: Ministro Ricardo Lewandowski. Brasília, 19 de agosto de 2008. Disponível em: <http://stf.jusbrasil.com.br/jurisprudencia/14719240/habeas-corpus-hc92921-ba>. Acesso em: 19 nov. 2016. 
$[\ldots .] "$.96 . A partir desse argumento, revelou que percebia restritivamente o conjunto de direitos fundamentais, por parte das pessoas jurídicas, dizendo-se que não estava convencida de “[...] que pessoas jurídicas poderiam ter liberdade [...] isto [...] vale para cá e para outras garantias constitucionais também"97. O Ministro Carlos Britto focou sua decisão nos pronomes indefinidos "ninguém" e "alguém" para sustentar que no caso do habeas corpus o que se protege é a pretensão deliberada de pessoa humana, excluindo, por essa razão, a possibilidade de pessoa jurídica figurar como paciente nesse tipo de ação constitucional ${ }^{98}$.

Por fim, o Ministro Lewandowski, vencido, ressaltou e advertiu que, impossibilitada a pessoa jurídica de utilizar um habeas corpus poderíamos ter como resultado "uma ação penal instaurada sem justa causa, flagrantemente sem justa causa, exclusivamente contra uma pessoa jurídica, não encontrará remédio em nosso ordenamento jurídico" ".99. Chamou a atenção que não haveria remédio jurídico para empresas processadas nas condições ocorridas no processo que então se decidia.

O tema da assistência judiciária gratuita, em favor da pessoa jurídica, foi ressaltado em agravo regimental, quando se ementou que:

Ao contrário do que ocorre relativamente às pessoas naturais, não basta a pessoa jurídica asseverar a insuficiência de recursos, devendo comprovar, isto sim, o fato de se encontrar em situação inviabilizadora da assunção dos ônus decorrentes do ingresso em juízo. ${ }^{100}$

A tentativa de se obstruir o uso da assistência judiciária gratuita por parte de empresas, contava como premissa de que a legislação de regência exigia que o interessado comprovasse que os gastos com serviços judiciários representariam "prejuízo próprio ou de sua família"101.

O Ministro Marco Aurélio sustentou que pessoas jurídicas podem invocar assistência judiciária gratuita, exigindo, no entanto, uma

[...] distinção que decorre da própria ordem natural das coisas [porque] presume-se relativamente às pessoas jurídicas em atividade, que estão no comércio, a detenção de recursos capazes de viabilizar o ingresso em juízo sem a citada gratuidade..$^{102}$

Assim, por intermédio de decisão judicial, condicionou-se o deferimento da assistência judiciária gratuita à pessoa jurídica à comprovação de situação específica e contingencial de impossibilidade de arcar com os ônus da litigância.

Ainda que em tema de reconhecimento de direitos fundamentais para pessoa jurídica de direito público, há importante precedente do STF que firma orientação sobre o assunto, e que, de algum modo, pode indicar um precedente para questões parecidas envolvendo pessoas jurídicas de direito privado. Referimo-nos a

96 BRASIL. Supremo Tribunal Federal. Habeas Corpus. HC 92.921-4-BA. Primeira turma. Relator: Ministro Ricardo Lewandowski. Brasília, 19 de agosto de 2008. Disponível em: <http://stf.jusbrasil.com.br/jurisprudencia/14719240/habeas-corpus-hc92921-ba>. Acesso em: 19 nov. 2016.

97 BRASIL. Supremo Tribunal Federal. Habeas Corpus. HC 92.921-4-BA. Primeira turma. Relator: Ministro Ricardo Lewandowski. Brasília, 19 de agosto de 2008. Disponível em: <http://stf.jusbrasil.com.br/jurisprudencia/14719240/habeas-corpus-hc92921-ba>. Acesso em: 19 nov. 2016.

98 BRASIL. Supremo Tribunal Federal. Habeas Corpus. HC 92.921-4-BA. Primeira turma. Relator: Ministro Ricardo Lewandowski. Brasília, 19 de agosto de 2008. Disponível em: <http://stf.jusbrasil.com.br/jurisprudencia/14719240/habeas-corpus-hc92921-ba>. Acesso em: 19 nov. 2016.

99 BRASIL. Supremo Tribunal Federal. Habeas Corpus. HC 92.921-4-BA. Primeira turma. Relator: Ministro Ricardo Lewandowski. Brasília, 19 de agosto de 2008. Disponível em: <http://stf.jusbrasil.com.br/jurisprudencia/14719240/habeas-corpus-hc92921-ba>. Acesso em: 19 nov. 2016.

100 BRASIL. Supremo Tribunal Federal. Agravo Regimental nos Embargos de Declaração na Reclamação. AgREDRCL 1.905-5/ SP. Tribunal Pleno. Relator: Ministro Marco Aurélio. Brasília, 15 de agosto de 2002. Disponível em: < http://redir.stf.jus.br/paginadorpub/paginador.jsp?docTP=AC\&docID=347936>. Acesso em: 19 nov. 2016.

101 Invocou-se a regra do $\int 1^{\circ}$ do art. $4^{\circ}$ da Lei $n^{\circ} 1.60$, de 5 de fevereiro de 1950, hoje revogada pelo Código de Processo Civil, que dispõe sobre a matéria.

102 BRASIL. Supremo Tribunal Federal. Agravo Regimental nos Embargos de Declaração na Reclamação. AgREDRCL 1.905-5/ SP. Tribunal Pleno. Relator: Ministro Marco Aurélio. Brasília, 15 de agosto de 2002. Disponível em: < http://redir.stf.jus.br/paginadorpub/paginador.jsp?docTP=AC\&docID=347936>. Acesso em: 19 nov. 2016. 
um mandado de injunção impetrado por Município em face do Congresso Nacional por conta de mora na confecção de lei complementar federal regulamentadora de consulta prévia e plebiscito referente à criação, incorporação, fusão e desmembramento de Municípios ${ }^{103}$.

Em jogo estava, do ponto de vista procedimental, a

[...] legitimação ativa para a impetração do writ os titulares de direitos subjetivos constitucionais relacionados às liberdades fundamentais, à nacionalidade, à soberania ou à cidadania. ${ }^{104}$

Nesse sentido, enfatizou o Ministro Gilmar Mendes,

Pressuposto do cabimento do mandado de injunção, portanto, não é apenas a existência de um direito fundamental cujo exercício seja inviável diante da ausência de norma regulamentadora, mas a própria legitimidade ativa do impetrante decorrente da titularidade direta do direito constitucional em questão. ${ }^{105}$

É pressuposto, também, com efeito, o reconhecimento (ou não) da possibilidade de uma pessoa jurídica manejar o writ.

Ao longo do voto condutor, para contrapeso, há citação de parecer da Procuradoria-Geral da República, no qual há referência a voto do Ministro Maurício Correa, em matéria análoga, quando se afirmou que:

Outorgar ao Município legitimidade ativa processual para impetrar mandado de segurança seria elastecer o conceito de direitos fundamentais além daquilo que a natureza jurídica do instituto permite. ${ }^{106}$

Ampliando a discussão relativa ao fato de que a pessoa jurídica de direito público deteria (ou não) titularidade para impetrar mandado de injunção e, portanto, um direito fundamental, o Ministro Gilmar Mendes assinalou que:

Não se deve negar aos Municípios, peremptoriamente, a titularidade de direitos fundamentais e a eventual possibilidade de impetração de ações constitucionais cabíveis para sua proteção. Se considerarmos o entendimento amplamente adotado de que as pessoas jurídicas de direito público podem, sim, ser titulares de direitos fundamentais, como, por exemplo, o direito à tutela judicial efetiva, parece bastante razoável vislumbrar a hipótese em que o Município, diante de omissão legislativa inconstitucional impeditiva do exercício desse direito, se veja compelido a impetrar mandado de injunção. A titularidade de direitos fundamentais tem como consectário lógico a legitimação ativa para propor as ações constitucionais destinadas à proteção efetiva desses direitos ${ }^{107}$.

O STF não conheceu do recurso, por maioria ${ }^{108}$. Assim, em socorro da prerrogativa de pessoas jurídicas impetrarem ações constitucionais resta apenas alguma construção conceitual, formulada com esforço a par-

103 BRASIL. Supremo Tribunal Federal. Mandado de Injunção. MI 725-0/RO. Tribunal Pleno. Relator: Ministro Gilmar Mendes. Brasília, 10 de maio de 2007. Disponível em: < http://stf.jusbrasil.com.br/jurisprudencia/757310/mandado-de-injuncao-mi725-ro>. Acesso em: 19 nov. 2016.

104 BRASIL. Supremo Tribunal Federal. Mandado de Injunção. MI 725-0/RO. Tribunal Pleno. Relator: Ministro Gilmar Mendes. Brasília, 10 de maio de 2007. Disponível em: <http://stf.jusbrasil.com.br/jurisprudencia/757310/mandado-de-injuncao-mi725-ro >. Acesso em: 19 nov. 2016.

105 BRASIL. Supremo Tribunal Federal. Mandado de Injunção. MI 725-0/RO. Tribunal Pleno. Relator: Ministro Gilmar Mendes. Brasília, 10 de maio de 2007. Disponível em: <http://stf.jusbrasil.com.br/jurisprudencia/757310/mandado-de-injuncao-mi725-ro>. Acesso em: 19 nov. 2016.

106 BRASIL. Supremo Tribunal Federal. Mandado de Injunção. MI 725-0/RO. Tribunal Pleno. Relator: Ministro Gilmar Mendes. Brasília, 10 de maio de 2007. Disponível em: <http://stf.jusbrasil.com.br/jurisprudencia/757310/mandado-de-injuncao-mi725-ro>. Acesso em: 19 nov. 2016.; BRASIL. Supremo Tribunal Federal. Mandado de Injunção. MI 537/SC. Relator: Ministro Maurício Correa. Brasília, 30 de agosto de 2001. Disponível em: <http://stf.jusbrasil.com.br/jurisprudencia/14819023/mandadode-injuncao-mi-537-sc-stf > . Acesso em: 19 nov. 2016.

107 BRASIL. Supremo Tribunal Federal. Mandado de Injunção. MI 725-0/RO. Tribunal Pleno. Relator: Ministro Gilmar Mendes. Brasília, 10 de maio de 2007. Disponível em: <http://stf.jusbrasil.com.br/jurisprudencia/757310/mandado-de-injuncao-mi725-ro >. Acesso em: 19 nov. 2016.

108 BRASIL. Supremo Tribunal Federal. Mandado de Injunção. MI 725-0/RO. Tribunal Pleno. Relator: Ministro Gilmar Mendes. Brasília, 10 de maio de 2007. Disponível em: <http://stf.jusbrasil.com.br/jurisprudencia/757310/mandado-de-injuncao-mi725-ro>. Acesso em: 19 nov. 2016. Ementa: O Tribunal, por maioria, não conheceu do mandado de injunção, nos termos do voto do Relator, vencido o Senhor Ministro Carlos Britto na questão do conhecimento para julgá-lo improcedente [...]. 
tir dos obiter dicta lançados ao longo das várias manifestações nesse mencionado processo.

Por fim, as discussões em torno do financiamento de campanhas eleitorais, por parte de pessoas jurídicas, também apresentam um conjunto expressivo de obiter dicta sobre a relação entre empresas e direitos fundamentais ${ }^{109}$. Bem entendido, o que se debatia era o efeito do poder econômico sobre os pleitos eleitorais, a então denominada "plutocratização do prélio eleitoral"110 pelo que, entre outros, a liberdade de expressão, por parte de pessoas jurídicas, revelou-se apenas como tópico lateral, ainda que enfatizado pelo então Ministro Joaquim Barbosa, como segue, com ênfases nossas:

Mas a Constituição não permite que determinados indivíduos possam se beneficiar de financiamento eleitoral arrojado, por parte de empresas, ao passo que a grande maioria dos eventuais candidatos não gozam dessa ajuda substantiva [...] Parece-me que é este o debate: saber se a empresa pode participar do debate político, como se cidadão fosse, financiando partidos e escolhendo, a partir de critérios que nós não conhecemos, aqueles para os quais ela [sic] darão contribuição. Esse é o debate essencial, parece-me ${ }^{111}$. (grifo nosso)

O Ministro Joaquim Barbosa inquietava-se com o fato de que "a questão crucial é [seria] saber se pessoas jurídicas voltadas à produção econômica podem fazê-lo em igualdade de condições com o cidadão [...]”"112. Já para o Ministro Luiz Fux, relator do processo:

[...] o exercício de direitos políticos é incompatível com a essência das pessoas jurídicas [...] uma empresa pode defender bandeiras políticas, como a de direitos humanos, causas ambientais etc., mas daí a bradar pela sua indispensabilidade no campo político, investindo vultosas quantias em campanhas eleitorais, dista uma considerável distância. ${ }^{113}$

De igual modo, condenando o financiamento de campanhas, por parte de pessoas jurídicas, o Ministro Dias Toffoli, com ênfases no original:

Observa-se, assim, a toda evidência, que o parágrafo único do art. $1^{\circ}$ e o caput do art. 14 da Constituição Federal não se destinam à pessoa jurídica: essa não pode votar, não pode ser votada e, caso pudesse votar, o voto não teria o mesmo valor, formal e material, para todas. Não há, portanto, comando ou princípio constitucional que justifique a participação de pessoas jurídicas no processo eleitoral brasileiro, em qualquer fase ou forma, já que não podem exercer a soberania pelo voto direto e secreto. ${ }^{114}$ (grifo nosso)

E ainda, o Ministro Toffoli enfatizou que "se as pessoas jurídicas não participam do processo democrático- pois não gozam de cidadania-, admitir que possam financiar o processo eleitoral é violar um dos fundamentos do Estado Democrático de Direito, qual seja, o da soberania popular”"115. O Ministro Barroso

109 BRASIL. Supremo Tribunal Federal. Ação Direta de Inconstitucionalidade. ADI 4.650/DF. Plenário. Relator: Ministro Luiz Fux. Brasília, 17 de setembro de 2015. Disponível em: <http://redir.stf.jus.br/paginadorpub/paginador. jsp?docTP=TP\&docID=10329542>. Acesso em: 20 nov. 2016.

110 A propósito, lê-se na ementa do mencionado julgado: “[...] Os limites previstos pela legislação de regência para a doação de pessoas jurídicas para as campanhas eleitorais se afigura assaz insuficiente a coibir, ou, ao menos, amainar, a captura do político pelo poder econômico, de maneira a criar indesejada 'plutocratização' do processo político".

111 BRASIL. Supremo Tribunal Federal. Ação Direta de Inconstitucionalidade. ADI 4.650/DF. Plenário. Relator: Ministro Luiz Fux. Brasília, 17 de setembro de 2015. Disponível em: <http://redir.stf.jus.br/paginadorpub/paginador. jsp?docTP=TP\&docID=10329542>. Acesso em: 20 nov. 2016.

112 BRASIL. Supremo Tribunal Federal. Ação Direta de Inconstitucionalidade. ADI 4.650/DF. Plenário. Relator: Ministro Luiz Fux. Brasília, 17 de setembro de 2015. Disponível em: <http://redir.stf.jus.br/paginadorpub/paginador. jsp?docTP=TP\&docID=10329542>. Acesso em: 20 nov. 2016.

113 BRASIL. Supremo Tribunal Federal. Ação Direta de Inconstitucionalidade. ADI 4.650/DF. Plenário. Relator: Ministro Luiz Fux. Brasília, 17 de setembro de 2015. Disponível em: <http://redir.stf.jus.br/paginadorpub/paginador. jsp?docTP=TP\&docID=10329542>. Acesso em: 20 nov. 2016.

114 BRASIL. Supremo Tribunal Federal. Ação Direta de Inconstitucionalidade. ADI 4.650/DF. Plenário. Relator: Ministro Luiz Fux. Brasília, 17 de setembro de 2015. Disponível em: <http://redir.stf.jus.br/paginadorpub/paginador. jsp?docTP=TP\&docID=10329542>. Acesso em: 20 nov. 2016.

115 BRASIL. Supremo Tribunal Federal. Ação Direta de Inconstitucionalidade. ADI 4.650/DF. Plenário. Relator: Ministro Luiz Fux. Brasília, 17 de setembro de 2015. Disponível em: <http://redir.stf.jus.br/paginadorpub/paginador. jsp?docTP=TP\&docID=10329542>. Acesso em: 20 nov. 2016. 
colocou os termos da questão, no que se refere às pessoas jurídicas, lembrando que se discutiam:

[...] nos limites e os modos de exercício dos Direitos Políticos pela cidadania; e, de certa forma, [...] dizendo que as pessoas jurídicas não têm direitos políticos. É isto mesmo que estamos nós estamos dizendo, nós que estamos votando contrariamente: pessoas jurídicas não são cidadãs, no sentido constitucional e, portanto, afigura-se legítima esta limitação que nós estamos impondo. Assim, há uma questão constitucional aqui: regras do jogo democrático e exercício dos Direitos Políticos. ${ }^{116}$

Centrado no argumento do poder econômico o Ministro Lewandowski entendeu que

[...] o financiamento de partidos e campanhas por empresas privadas [...] fere profundamente o equilíbrio dos pleitos, que, nas democracias, deve reger-se pelo vetusto princípio que os anglo-saxões denominam de one man one vote, significando que cada cidadão deve corresponder um voto, com igual peso e idêntico valor. ${ }^{17}$

Ainda com foco nesse argumento, adiantou:

As pessoas jurídicas, ademais, não votam e não podem ser eleitas, daí porque não há a menor razão de permitir que elas tenham qualquer participação no processo eleitoral, nem mesmo mediante apoio financeiro a partidos ou candidatos, sobretudo porque elas, por definição, defendem interesses materiais, mais especificamente o lucro delas mesmas, pretensão incompatível com a permanente aspiração de aprimorar o bem comum que promana da somatória dos votos individuais dos cidadãos ${ }^{118}$.

De igual modo, a Ministra Rosa Weber entendeu que as

[...] pessoas jurídicas não são efetivas detentoras dos direitos políticos por excelência [...] uma vez reservados às pessoas naturais ou físicas que preencham os requisitos constitucionais e legais a voto, a iniciativa popular e as consultas por meio do plebiscito e do referendo. ${ }^{119}$

O Ministro Barroso, porém, enfatizou que a questão é política e que ao Congresso caberia decidir “[...] se a empresa pode ou não participar do financiamento eleitoral" ${ }^{120}$. Nessa linha, colhe-se comentário de autores, para quem, "seria necessário [...] uma reforma constitucional, estendendo às pessoas jurídicas a proteção constitucional" 121 .

Assim, desse conjunto de decisões pode-se inferir que o exercício absoluto e ilimitado de direitos fundamentais, por parte das empresas, é circunstância tratada, realisticamente, pela jurisprudência do STF, no contexto das várias condicionantes acima elencadas.

\section{Comentários finais e Conclusões}

A efetivação dos direitos sociais exige obtenção e alocação de recursos que dependem do funcionamento ótimo da economia e da atividade privada. Esta última se relaciona, diretamente, com a realização de vários

116 BRASIL. Supremo Tribunal Federal. Ação Direta de Inconstitucionalidade. ADI 4.650/DF. Plenário. Relator: Ministro Luiz Fux. Brasília, 17 de setembro de 2015. Disponível em: <http://redir.stf.jus.br/paginadorpub/paginador. jsp?docTP=TP\&docID=10329542>. Acesso em: 20 nov. 2016.

117 BRASIL. Supremo Tribunal Federal. Ação Direta de Inconstitucionalidade. ADI 4.650/DF. Plenário. Relator: Ministro Luiz Fux. Brasília, 17 de setembro de 2015. Disponível em: <http://redir.stf.jus.br/paginadorpub/paginador. jsp?docTP=TP\&docID=10329542>. Acesso em: 20 nov. 2016.

118 BRASIL. Supremo Tribunal Federal. Ação Direta de Inconstitucionalidade. ADI 4.650/DF. Plenário. Relator: Ministro Luiz Fux. Brasília, 17 de setembro de 2015. Disponível em: <http://redir.stf.jus.br/paginadorpub/paginador. jsp?docTP=TP\&docID=10329542>. Acesso em: 20 nov. 2016.

119 BRASIL. Supremo Tribunal Federal. Ação Direta de Inconstitucionalidade. ADI 4.650/DF. Plenário. Relator: Ministro Luiz Fux. Brasília, 17 de setembro de 2015. Disponível em: <http://redir.stf.jus.br/paginadorpub/paginador. jsp?docTP=TP\&docID=10329542> . Acesso em: 20 nov. 2016.

120 BRASIL. Supremo Tribunal Federal. Ação Direta de Inconstitucionalidade. ADI 4.650/DF. Plenário. Relator: Ministro Luiz Fux. Brasília, 17 de setembro de 2015. Disponível em: <http://redir.stf.jus.br/paginadorpub/paginador. jsp?docTP=TP\&docID=10329542>. Acesso em: 20 nov. 2016.

121 DIMOULIS, Dimitri; MARTINS, Leonardo. Teoria geral dos direitos fundamentais. São Paulo: Revista dos Tribunais, 2007 . p. 99. 
direitos fundamentais, especialmente quando emprega e se vincula a quem lhe presta serviços. As empresas, assim, são, também, importantes meios para alcançar os fins fixados pela agenda da profusão de direitos fundamentais, constatando-se mais uma face de sua dinâmica posição enquanto agente de transformação.

Ordem social e ordem econômica suscitam relação de proximidade matizada, também, pelos tomadores de risco. Há ênfase no papel e importância do empresário, que igualmente é agente de efetivação de direitos sociais e que, para tal, deve ser instrumentalizado. Reverbera entre nós o conceito de empresa tal como construído no estado corporativo italiano, temperado com o repúdio para com uma ordem jurídica fascista e autoritária. O conceito contemporâneo de mercado, ou, pelo menos, suas demandas, alteram essa percepção inicial. O conceito de empresário descolou-se da ordem ditatorial italiana.

Para que as empresas possam se inserir de modo cada vez mais positivo em esforço coletivo de criação de riquezas para que se contemplem necessidades gerais (que são infinitas) precisam do reconhecimento e da garantia de prerrogativas instrumentais. Essa equação sugere que se pensem modos de fortalecimento da atividade empresarial, o que pode se efetivar mediante o reconhecimento de alguns direitos, que lembram a agenda dos direitos fundamentais, a exemplo da liberdade de expressão comercial e da titularidade para ser compensada por danos morais, que a jurisprudência também já adotou.

No entanto, há um elemento prático que orienta a discussão, no sentido de que há limitações de ordem natural para que pessoas jurídicas não possam protagonizar alguns desses direitos, a exemplo do habeas corpus, que se prestaria, em princípio, para sufragar a liberdade de ir e vir. A jurisprudência do STF é marcadamente realista, mitigando a ampla possibilidade de atuação das pessoas jurídicas, a exemplo da vedação para o financiamento de campanhas eleitorais ou para o manejo de algumas ações constitucionais.

Não se pode perder de vista que o destinatário final de norma asseguradora de direito fundamental seja a pessoa humana. Essa percepção exige vetor hermenêutico que entenda que a pessoa jurídica existe em função da pessoa humana. A empresa nada mais é do que um esforço que reúne indivíduos e que, portanto, reflete essas existências pessoais. Por isso, na razão direta de sua instrumentalização, em princípio, varia, também, o fortalecimento das pessoas humanas, núcleo dos direitos fundamentais, calcados no reconhecimento das respectivas dignidades.

\section{REFERÊNCIAS BIBLIOGRÁFICAS}

ALEMANHA. Constituição da Alemanha. Disponível em: < https:/ /www.btg-bestellservice.de/pdf/80208000. pdf>. Acesso em: 14 nov. 2016.

ALTMANN, Andrew. Critical Legal Studies: a liberal critique. New Jersey: Princeton University Press, 1993.

AMARAL, Francisco. Direito civil: introdução. Rio de Janeiro: Renovar, 2014.

ANDRADE, José Carlos Vieira de. Os direitos fundamentais na Constituição Portuguesa de 1976. Coimbra: Almedina, 2006.

ARNOLDI, Paulo Roberto Colombo. Teoria geral do direito comercial: introdução à teoria da empresa. São Paulo: Saraiva, 1998.

ASQUINI, Alberto. Perfis da Empresa. Revista de Direito Mercantil, Industrial, Econômico e Financeiro, São Paulo, v. 35, n. 104, p. 109-126, out./dez. 1966.

BARBOSA FILHO, Marcelo Fortes. Comentários ao art. 966 do Código Civil. In: PELUSO, Cezar (Coord.). Código civil comentado. Barueri: Manole, 2010. p.972.

BARROSO, Luís Roberto. Curso de direito constitucional contemporâneo. São Paulo: Saraiva, 2009. 
BARROSO, Luís Roberto. Direito constitucional brasileiro: o problema da federação. Rio de Janeiro: Forense, 1982.

BARROSO, Luís Roberto. Interpretação e aplicação da constituição. São Paulo: Saraiva, 2009.

BOBBIO, Norberto. A era dos direitos. Rio de Janeiro: Elsevier, 2004.

BRASIL. Constituição (1988). Constituição da República Federativa do Brasil. Disponível em: <http://www.planalto.gov.br/ccivil_03/Constituicao/Constituicao.htm>. Acesso em: 14 nov. 2016.

BRASIL. Lei n. 10.406, de 10 de janeiro de 2002. Código Civil Disponível em: <http://www.planalto.gov.br/ ccivil_03/leis/2002/L10406.htm>. Acesso em: 14 nov. 2016.

BRASIL. Projeto de Lei n. 1.572 de 2011. Institui o Código Comercial. Disponível em: <http://www.camara. gov.br/proposicoesWeb/fichadetramitacao?idProposicao=508884>. Acesso em: 14 nov. 2016.

CAMPOS, Francisco. Antecipações à reforma política. Rio de Janeiro: José Olympio, 1940.

CAMPOS, Francisco. Pareceres do consultor-geral da república. Rio de Janeiro: A. Coelho Branco Filho, 1952.

CANARIS, Claus-Wilhelm. Direitos fundamentais e direito privado. Coimbra: Almedina, 2006.

CANOTILHO, J. J. Gomes. "Brancosos” e interconstitucionalidade: itinerário dos discursos sobre a historicidade constitucional. Coimbra: Almedina, 2006.

CANOTILHO, J. J. Gomes. Direito constitucional. Coimbra: Almedina, 1993.

COELHO, Fábio Ulhoa. Manual de direito comercial: direito de empresa. São Paulo: Revista dos Tribunais, 2016.

COMPARATO, Fábio Konder. A afirmação histórica dos direitos humanos. São Paulo: Saraiva, 2005.

COMPARATO, Fábio Konder. Direito empresarial: estudos e pareceres. São Paulo: Saraiva, 1990.

DANTAS, Francisco San Tiago. Programa de direito civil. Rio de Janeiro: Estácio de Sá, 1977.

DIMOULIS, Dimitri; MARTINS, Leonardo. Teoria geral dos direitos fundamentais. São Paulo: Revista dos Tribunais, 2007.

FAORO, Raymundo. Os donos do poder: Formação do patronato político brasileiro. São Paulo: Globo, 2001.

FERRARA, Francesco. Trattato di diritto civile italiano: dottrine generali. Roma: Athenaeum, 1921. v.1.

FIGUEIREDO, Leonardo Vizeu. Lições de direito econômico. Rio de Janeiro: Gen, Forense, 2011.

FORGIONI, Paula A. A evolução do direito comercial brasileiro: da mercancia ao mercado. São Paulo: Revista dos Tribunais, 2016.

GERHARDT, Michael J. The power of precedent. New York: Oxford University Press, 2008.

GIAMBIAGI, Fábio. Reforma da previdência: o encontro marcado. São Paulo: Campus-Elsevier, 2007.

GIAMBIAGI, Fabio; ALÉM, Ana Cláudia. Finanças públicas: teoria e prática no Brasil. São Paulo: CampusElsevier, 2011.

GRAU, Eros Roberto. A ordem econômica na constituição de 1988. São Paulo: Malheiros, 2010.

HANSFORD, Thomas G.; SPRIGGS II, James F. The politics of precedent on the U.S. supreme court. Oxford: Princeton University Press, 2006.

HESSE, Konrad. A força normativa da constituição. Porto Alegre: Sergio Antonio Fabris Editor, 1991.

HOLMES, Stephen; SUNSTEIN, Cass. The cost of rights-why liberty depends on taxes. New York, London: W. M. Norton, 1999. 
LOPES, Ana Frazão de Azevedo. Empresa e propriedade: função social e abuso de poder econômico. São Paulo: Quartier Latin, 2006.

MAMEDE, Gladston. Manual de direito empresarial. São Paulo: Atlas, 2006.

MARTINS, Fran. Curso de direito comercial. Rio de Janeiro: Forense, 1967.

MELLO, Patrícia Perrone. Precedentes: o desenvolvimento judicial do direito no constitucionalismo contemporâneo. Rio de Janeiro: Renovar, 2008.

MENDES, Gilmar Ferreira. Estado de direito e jurisdição constitucional. São Paulo: Saraiva, 2011.

NEVES, Marcelo. A constitucionalização simbólica. São Paulo: Martins Fontes, 2013.

NEVES, Marcelo. Transconstitucionalismo. São Paulo: Martins Fontes, 2012.

NORTH, Douglass C. Institutions, institutional change and economic perfomance. Cambridge: Cambridge University Press, 2007.

NUSDEO, Fábio. Curso de economia: introdução ao direito econômico. São Paulo: Revista dos Tribunais, 2016.

PANTOJA, Teresa Cristina G. Anotações sobre pessoas jurídicas. In: TEPEDINO, Gustavo (Org.). A parte geral do novo Código Civil. Rio de Janeiro: Renovar, 2003.

PORTUGAL. Constituição da República Portuguesa. Disponível em: < http://www.parlamento.pt/Legislacao/ Paginas/ConstituicaoRepublicaPortuguesa.aspx>. Acesso em: 14 nov. 2016.

POSNER, Richard. The problems of jurisprudence. Cambridge: Harvard University Press, 1993.

RIBAS, Joaquim. Direito civil brasileiro. Rio de Janeiro: Rio, 1977.

ROSAS, João Grandino. Sociedade comercial e estado. São Paulo: Saraiva, 1995.

ROTHENBURG, Walter Claudius. Direitos fundamentais. Rio de Janeiro: Forense, 2014.

SALAMA, Bruno Meyerhof. O fim da responsabilidade limitada no Brasil: história, direito e economia. São Paulo: Malheiros, Fundação Getúlio Vargas, 2014.

SARLET, Ingo Wolfgang. A Eficácia dos direitos fundamentais: uma teoria dos direitos fundamentais na perspectiva constitucional. Porto Alegre: Livraria do Advogado, 2015.

SARMENTO, Daniel. Dignidade da pessoa humana: conteúdo, trajetórias, metodologia. Belo Horizonte: Fórum, 2016.

SHECAIRA, Sérgio Salomão. Responsabilidade penal da pessoa jurídica. São Paulo: Método, 2003.

SILVA, Virgílio Afonso. Direitos fundamentais. São Paulo: Malheiros, 2009.

SUNSTEIN, Cass R. Free markets and social justice. New York: Oxford University Press, 1997.

UNGER, Roberto Mangabeira. The critical legal studies movement. Cambridge: Harvard University Press, 1986.

UNGER, Roberto Mangabeira. What should legal analysis become? London: Verso, 1996.

VIANNA, Oliveira. Instituições políticas brasileiras. São Paulo: Universidade de São Paulo, 1987.

ZYLBERSZTAJN, Decio; SZTAJN, Rachel. Direito e economia: análise econômica do direito e organizações. Rio de Janeiro: Elsevier, 2005. 
Para publicar na revista Brasileira de Políticas Públicas, acesse o endereço eletrônico www.rbpp.uniceub.br

Observe as normas de publicação, para facilitar e agilizar o trabalho de edição. 